Article

\title{
A New Calcareous Nannofossil Record from the Lower Jurassic of Kermanshah, Western Iran: Implications for Biostratigraphy and Evolutionary Reconstructions
}

\author{
Asad Abdi ${ }^{1,2}$, Emanuela Mattioli ${ }^{3,4, *}$ and Beatriz Bádenas ${ }^{5}$ \\ 1 Zaminrizkavan Co., Ltd., Tehran 1481654886, Iran; Asadabdi656@gmail.com \\ 2 Department of Geology, Faculty of Sciences, Ferdowsi University of Mashhad, Mashhad 9177948974, Iran \\ 3 Univ Lyon, UCBL, ENSL, UJM, CNRS, LGL-TPE, F-69622 Villeurbanne, France \\ 4 Institut Universitaire de France (IUF), 1 Rue Descartes, F-75231 Paris, France \\ 5 Department of Earth Sciences, Faculty of Sciences, University of Zaragoza, 50009 Zaragoza, Spain; \\ bbadenas@unizar.es \\ * Correspondence: emanuela.mattioli@univ-lyon1.fr
}

check for

updates

Citation: Abdi, A.; Mattioli, E.;

Bádenas, B. A New Calcareous

Nannofossil Record from the Lower Jurassic of Kermanshah, Western Iran: Implications for Biostratigraphy and Evolutionary Reconstructions. Geosciences 2022, 12, 59. https:// doi.org/10.3390/geosciences12020059

Academic Editors: Maria

Helena Henriques and

Jesus Martinez-Frias

Received: 19 December 2021

Accepted: 21 January 2022

Published: 27 January 2022

Publisher's Note: MDPI stays neutral with regard to jurisdictional claims in published maps and institutional affiliations.

Copyright: () 2022 by the authors. Licensee MDPI, Basel, Switzerland. This article is an open access article distributed under the terms and conditions of the Creative Commons Attribution (CC BY) license (https:// creativecommons.org/licenses/by/ $4.0 /)$.

\begin{abstract}
Calcareous nannofossils are used here for the first time in order to establish a precise biostratigraphic framework for the Kermanshah Radiolarite Formation, an outcropping in Western Iran. The new data presented here challenge the previous tentative age interpretations (Pliensbachian to early Toarcian) based upon radiolarians. Calcareous nannofossil assemblages and events unequivocally indicated that the pelagic limestones and marls are late Sinemurian in age (NJT 3b nannofossil subzone), and that these are thrusted over shales and cherts dated as uppermost Sinemurian (NJT 3b-c nannofossil subzone) and lowermost Pliensbachian (NJT 4 nannofossil zone). This result leads not only to reconsideration of the age of the radiolarite formations, which are widespread in the Zagros orogenic system, but also a better understanding of the stratigraphic relationships between the various lithological units known in the area. Besides these new stratigraphic inferences, the calcareous nannofossil assemblages of the uppermost Sinemurian-lowermost Pliensbachian successions revealed the common presence of new morphologies of the Mitrolithus genus, never described before. These findings allow for the description of three new species, M. montgolfieri, M. pseudonannoconus, and $M$. tethysiensis, and reveal the existence of homeomorphy between the spine structure of conical Lower Jurassic coccoliths and the widespread Cretaceous nannoconids.
\end{abstract}

Keywords: calcareous nannofossils; biostratigraphy; taxonomy; Lower Jurassic; Kermanshah Radiolarite Basin; West Iran

\section{Introduction}

The Lower Jurassic Kermanshah Radiolarite Formation crops out in West Iran within the Zagros orogenic system, which extends from southwest Iran to north Iraq. This mountain chain was produced by the collision between the Arabian Plate and the Cimmerian Block in central Iran. From a paleogeographic point of view, the Kermanshah Basin was located to the north-east of the Arabian continental platform and was separated from the Neo-Tethys Ocean by the Bisotoun shallow-carbonate platform (Figure 1A-C). The studied sections in the Kermanshah area are composed of shales, limestones and cherts or radiolarites, with intercalated pyroclastic, oolitic/bioclastic packstone/grainstone and calciturbidite deposits. These sediments were previously dated as Pliensbachian-Aalenian [1], based on a few samples where radiolarians were recorded. Specifically, the recovery of Praeconocaryomma bajaensis and Bagotum modestum in the lowermost part of the limestone-dominated member provided a Pliensbachian or early Toarcian age determination (Pessagno and Whalen, in Carter et al. [2]). Within the ribbon chert-dominated member, the presence of Katroma sp. in its lowermost part provided an age older than early Toarcian [3], whereas 
Elodium sp. in its upper part indicated a Toarcian and Aalenian age [3]. However, because of the wide range of radiolarian taxa and the scarcity and poor preservation of radiolarian findings (most of the fossil specimens have undergone calcite replacement in Kermanshah area sediments), additional biostratigraphic data are required in order to accurately date these Lower Jurassic successions.

For this purpose, a detailed analysis of calcareous nannofossil content was undertaken in the Kermanshah sedimentary successions. Although a significant number of the selected samples were barren in terms of nannofossils, some levels delivered a rich nannofossil assemblage that allowed for the precise dating of some parts of the succession. Published Jurassic nannofossil zonal schemes (e.g., Barnard and Hay [4], Hamilton [5,6], Medd [7], Bown [8], Bown et aI. [9], Mattioli and Erba, [10], Ferreira et al. [11]) are based on successions in north and west Europe, and other (mainly Tethyan) areas in the Northern Hemisphere. The few published records of Lower Jurassic nannofossils from the south-east Tethys come from Sulawesi [12], Timor [8] or from offshore north-west Australia [13], and are very scattered.

The new biostratigraphic framework for the Lower Jurassic in the Kermanshah area presented in this paper allows for a more precise dating of the Kermanshah Radiolarite Formation. The new nannofossil data are especially relevant because very few studies on calcareous nannofossils are available from such Lower Jurassic, low-latitude sites located much further to the east than the well-known western Tethys sites. In addition, some samples of the Kermanshah Formation revealed new nannofossil species never documented before of the genus Mitrolithus, a typical Tethyan Lower Jurassic taxon.

\section{Geological Context of the Studied Succession}

According to paleogeographic reconstructions, the Kermanshah Radiolarite Basin (western Iran) developed during the Mesozoic Era at the western border of the central Neo-Tethys Ocean and northeast of the Arabian platform located at the eastern edge of Gondwana [14-19] (Figure 1A,B). More specifically, the Kermanshah Basin successions are exposed in the crush zone or High Zagros Belt (HZB in Figure 1C), within the Zagros orogenic system. The earliest extensional phase, which marks the opening of the Kermanshah Basin, occurred during the Late Triassic (e.g., [20]). The rifting continued through the Jurassic $[18,21]$, and the tectonic inversion generating the Zagros orogenic system began in the Late Cretaceous. The latter phase originated in response to the obduction of the Tethyan oceanic lithosphere onto the Arabian passive margin, and the collision between the Arabian Plate and the Central Iran Cimmerian Block [20-23].

The High Zagros Belt includes four geological units (Figure 1D): the Bisotoun limestones, belonging to the Bisotoun carbonate platform, which separated the Kermanshah Basin from the Arabian continental platform [1,18,22-24] Figure 1E); a transition zone between the Bisotoun limestone and the Kermanshah deposits; the Kermanshah Basin succession; and the Neo-Tethys ophiolitic obduction nappe [18,25-27] (Figure 1C). 

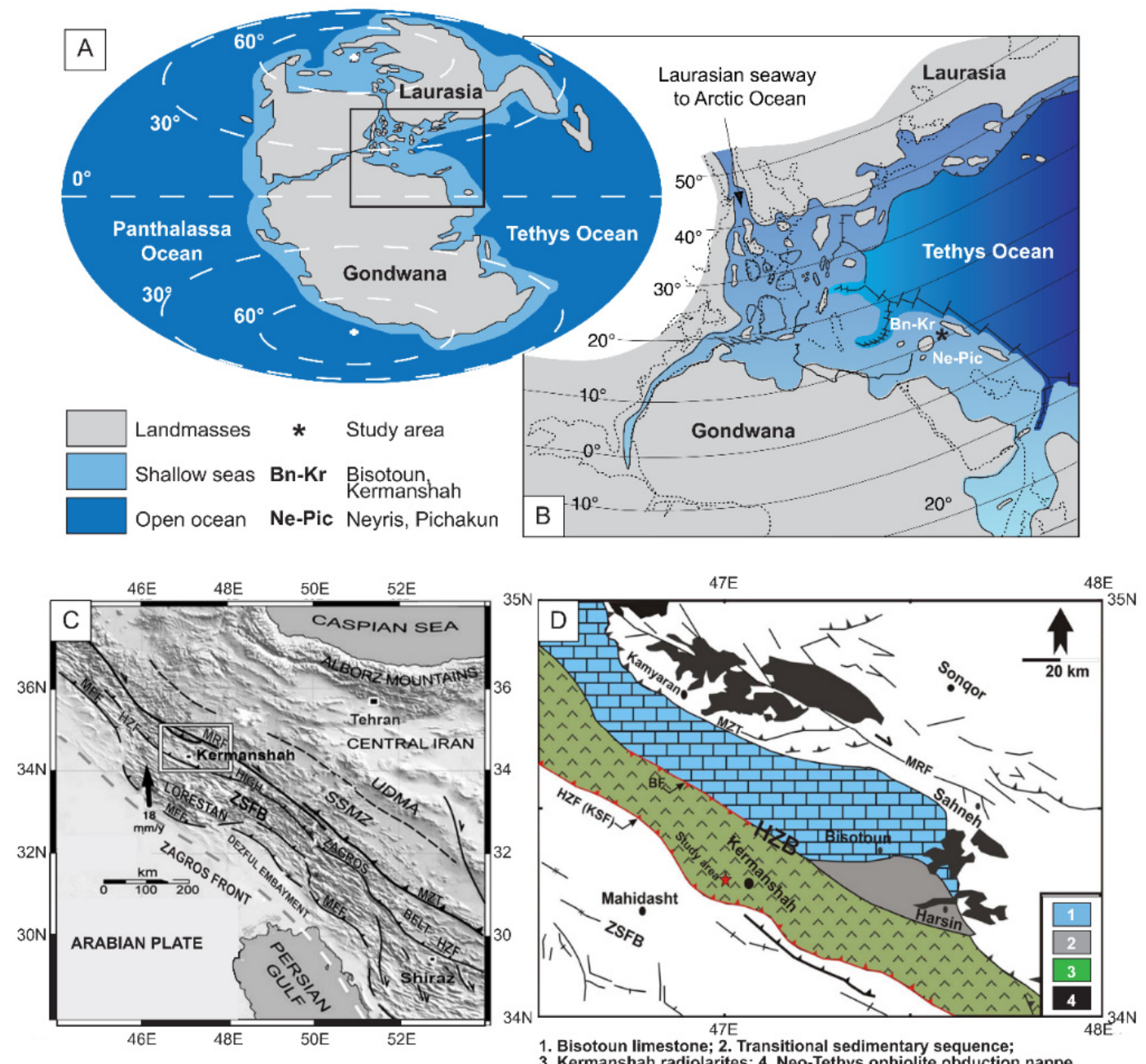

3. Kermanshah radiolarites; 4 . Neo-Tethys ophiolite obduction nappe

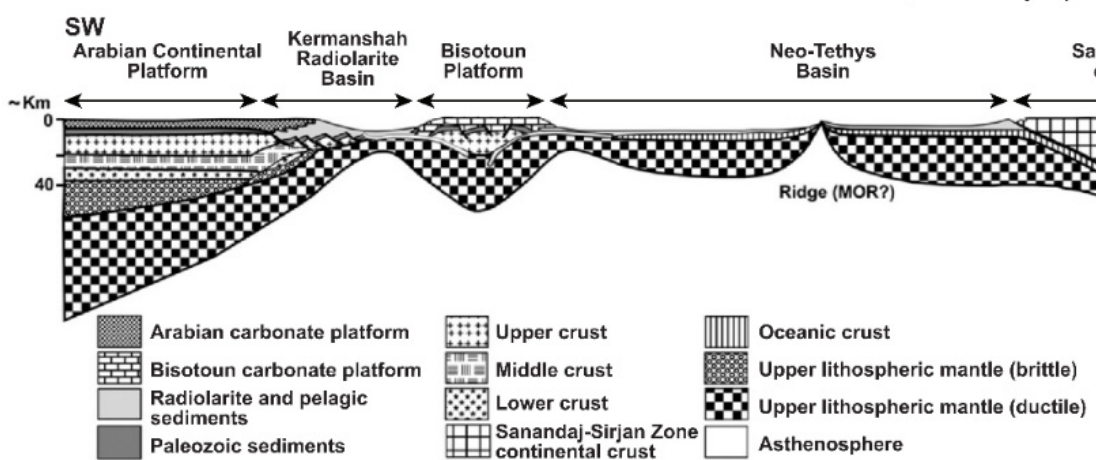

NE anandaj-Sirjan Zone continental crus

Figure 1. (A) Paleogeographic map of Lower Jurassic (modified after Blakey [28]. (B) Paleogeography of the western Tethys with location of the studied Kermanshah Radiolarite Basin (modified after Bassoulet et al. [15]). (C) Regional map of the Zagros fold-and-thrust belt, indicating the location of the studied area of Kermanshah in west Iran (see rectangle). Topography comes from http:// edc.usgs.gov (accessed on 18 December 2021). (D) Simplified geological map indicating the main tectonostratigraphic domains and showing the position of the studied section near Kermanshah (red star) in the High Zagros Belt (HZB). The Kermanshah radiolarite outcrops are limited by the Bisotoun Fault (BF) to the north and the Kuh-e-Sefid Fault (KSF = HZF) to the south (after Abdi et al. [1], and Navabpour et al. [18], modified). (E) Sketch showing a cross-section from the Arabian continental platform to the Sanandaj-Sirjan active margin for the Early Jurassic, with the location of the Kermanshah Radiolarite Basin. The latter was separated from the Neo-Tethys Basin by the Bisotoun carbonate platform (modified from Wrobel-Daveau et al. [22]). 
A variety of marine sedimentary rocks, including radiolarites, pelagic limestones, shales and event deposits (pyroclastic deposits, internal wave deposits, calciturbidites, and debris flows) accumulated in the Kermanshah Basin during the Mesozoic [17,23,27]. Our work focused on two sections, $\sim 2 \mathrm{~km}$ apart, in the Kermanshah area: the Kani Sad $\left(34^{\circ} 19^{\prime} 11^{\prime \prime} \mathrm{N}\right.$ and $\left.47^{\circ} 02^{\prime} 04^{\prime \prime} \mathrm{E}\right)$ and Sad sections $\left(34^{\circ} 19^{\prime} 11.1^{\prime \prime} \mathrm{N}\right.$ and $\left.47^{\circ} 02^{\prime} 03.8^{\prime \prime} \mathrm{E}\right)$. The Kani Sad section was previously studied by Abdi et al. $[1,23,24]$, who presented the stratigraphic and sedimentological framework of the outcropping units. Three Lower Jurassic informal lithological members, dated as Pliensbachian to Aalenian based on the radiolarian record, were differentiated (Table 1): J.1, mainly including cherts; J.2, formed by pelagic limestones with marl intercalations and event deposits (internal wave deposits, pyroclastic deposits); and J.3, mainly consisting of ribbon cherts (i.e., chert-shale alternations). The Kani Sad and Sad sections studied in this work include part of the described successions in Abdi et al. $[1,23,24]$, but new biostratigraphic data allowed for improved stratigraphy of the units and led us to provisionally rename some of them, awaiting new biostratigraphic data and formal lithostratigraphic definition (Table 1). In particular, the studied succession encompasses two lithological members, named here J.0 and J.1, based on the present outcrop position (Figure 2). The J.0 member is dominated by shales and cherts with intercalated pyroclastic deposits and calciturbidites (calcarenites), and partly coincides with the J.1 member (cherts) of Abdi et al. [1]. In the Kani Sad and Sad sections, this member is $12 \mathrm{~m}$ and $6 \mathrm{~m}$ thick, respectively. The J.1 member is $20 \mathrm{~m}$ thick and outcrops in the Kani Sad section, and it coincides with the J.2 unit (pelagic limestones with marl intercalations) described by Abdi et al. $[1,23,24]$, which was previously dated by radiolarian fossils as Pliensbachian pro parte to early Toarcian.

Table 1. Synthesis of the stratigraphic members described in the studied Kermanshah area in previous and present work.

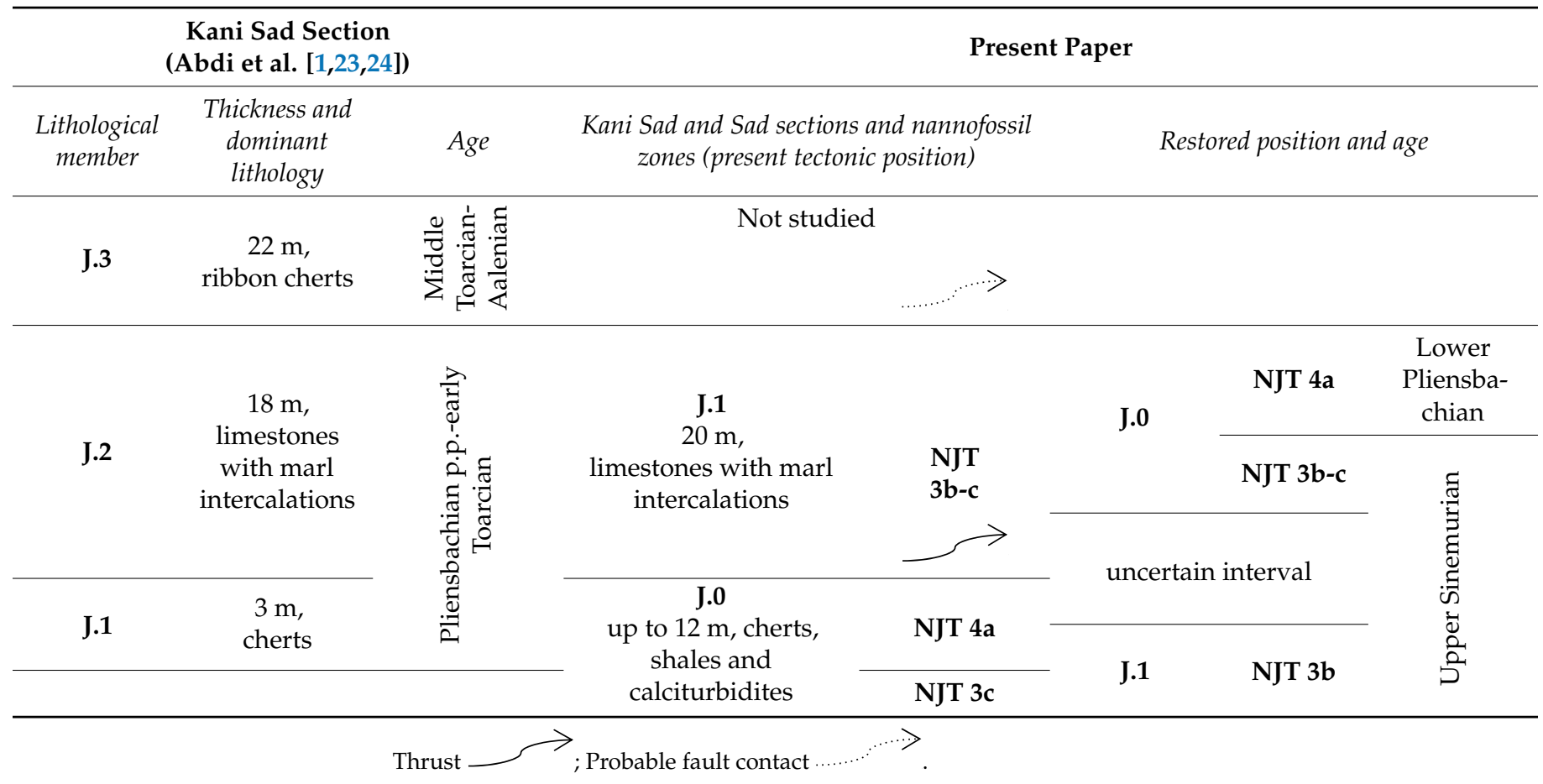

As the shaly units of the J.0 member of the Kani Sad and Sad sections are part of two limbs of a syncline (see Results section below), it is indicated that J.0 is in fact younger in age that J.1, such that J.1 is thrusted over J.0 (Figure 2 and Table 1). 


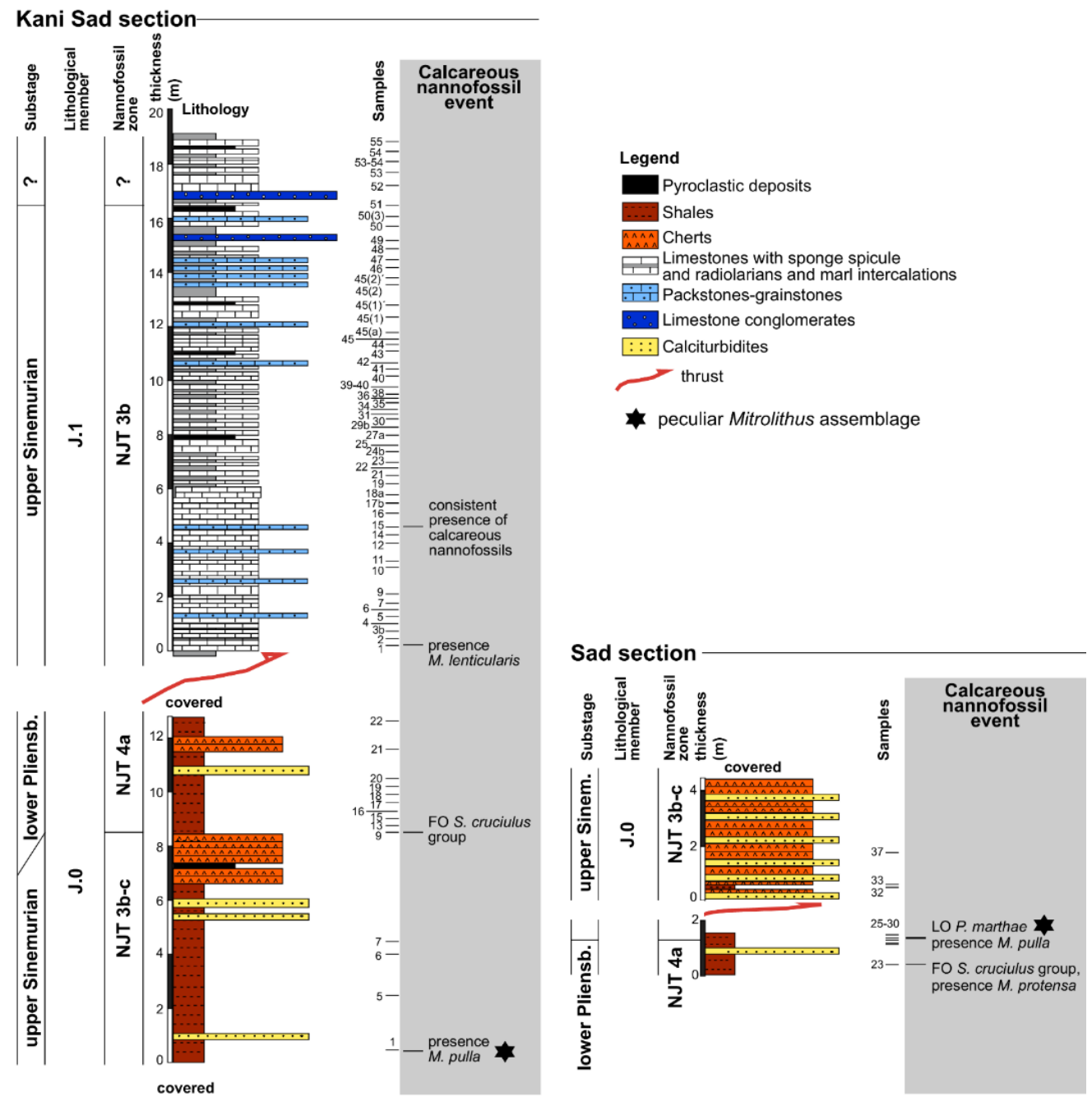

Figure 2. Stratigraphic logs of the Kani Sad and Sad sections, indicating the position of nannofossil samples (partly modified after Abdi et al. $[1,23,24]$ ). The first occurrence (FO) of the S. cruciulus group is reported, as Similiscutum cruciulus, Similiscutum orbiculus and Similiscutum avitum likely represent different ecophenotypes of the same species (Mattioli et al. [29]). Note that, according to nannofossil biostratigraphy, the J.0 member of the Kani Sad and Sad sections is younger than the J.1 member. The shaly units of the J.0 member of the Kani Sad and Sad sections are part of two limbs of a syncline structure, which is over-thrusted by the siliceous mudstones and grainstones of the J.1 member. The lower part of the Sad section is stratigraphically reversed, as also shown by the position of nannofossil zones.

\section{Nannofossil Sampling and Analysis}

A total of 77 samples were studied for calcareous nannofossils. Samples came from the carbonate-rich beds, namely 23 samples from the J.0 unit (14 from the Kani Sad section and nine from the Sad section), and 54 samples from the J.1 unit in the Kani Sad section (Figure 2 and Table S1). Smear slides were prepared following the method described in Bown and Young [30]. For each rock sample, a small amount of powdered rock was mixed with a drop of water and spread onto a cover slide; the water was evaporated on a hot plate, and then the slide was mounted on a microscope slide using Rhodopas B resin (polyvinyl acetate). The slides were observed using a Leica DM750P polarising microscope at 1000 $\times$ magnification. Three transverses of each slide were systematically scanned (a surface of approximately $19.2 \mathrm{~mm}^{2}$ ) and all encountered calcareous nannofossils were counted. The preservation of nannofossils was evaluated according to the criteria of etching and overgrowth described by Roth [31]. Semi-quantitative abundance classes were calculated 
(rare, few, common and abundant) according to the species and specimen abundance in a single field of view [30].

The taxonomy of the studied specimens was based on the seminal work of Bown [8] for muroliths (i.e., coccoliths characterized by a simple structure with calcite elements of the distal shield extending vertically, representing the earliest coccoliths to have appeared in the Late Triassic [8]). For placoliths (i.e., coccoliths composed of two shields which lie on top of one another, and are connected by a central tube; the two shields show radial calcite elements; Bown [8]), the taxonomy of de Kaenel and Bergen [32] and Mattioli et al. [29] was used.

For biostratigraphy, the following standard zonations were used: Bown [8], updated by Bown and Cooper [33] for the north-west Tethys areas (especially England, Germany and Austria); Mattioli and Erba [10] for the south-west Tethys (mainly central and northern Italy, and south-east France); and Ferreira et al. [11] for the proto-Atlantic region (Portugal).

\section{Results}

\subsection{Calcareous Nannofossil Biostratigraphy}

In the stratigraphically lower part of the Kani Sad section (J.1 member, thrusted over the J.0 member; Table 1 and Figure 2; a comprehensive list of the recorded species with author is provided in Appendix A), 39 of the 54 samples were barren of nannofossils, and the remaining samples yielded poorly preserved and low-diversity nannofossil assemblages. However, the productive samples included biostratigraphically useful taxa, including incertae sedis Schizosphaerella spp. and the coccoliths Mitrolithus elegans, M. lenticularis, M. jansae, Parhabdolithus robustus and sporadic P. marthae (amongst other coccoliths), with abundances varying from rare to few (one specimen in 31-150 fields of view to one specimen in 15-30 fields of view).

In the stratigraphically upper part of the Kani Sad section (J.0 member), most of the samples bore nannofossils, and displayed a relatively richer assemblage as some species (such as M. elegans) were few-to-common in discrete levels. This interval is also biostratigraphically relevant because it includes the first occurrence (FO) of bi- and three-shielded placoliths, namely Similiscutum avitum in sample J.0-9 and S. orbiculus in sample J.0-18, and of Mazaganella pulla in sample J.0-1. These occurrences are particularly relevant because they allow for the correlation of the Kermanshah section with other stratigraphically well-constrained sections of the western Tethys (see discussion). The J.0 member in the Sad section (reversed portion underlying the over-thrust; Figure 2 and Table S1) revealed the richest nannofossil content with several species of the genus Mitrolithus being common in the slides. Species of Similiscutum also occur, although discontinuously, along with M. pulla and M. protensa. Parhabdolithus marthae likely last occurred (LO) in this interval (sample J.0-28).

The most striking feature of the nannofossil assemblages in the stratigraphically upper parts of the Kani Sad and Sad sections was the morphological diversity of the genus Mitrolithus (black stars in Figure 2). In particular, huge variability was observed for Mitrolithus elegans, which is a basket-shaped murolith-coccolith, slightly flaring in side view, characterized by a spine that is narrow at its base, broadening out and rounding off at its top. This form may occur as entire coccoliths or as isolated spines. Detached spines are circular in plan view and have been described as a separate species (Alvearium dorsetense Black [34]). These coccoliths recorded in the J.0 member bearing well-developed spines with peculiar morphologies have been described as new species here (see taxonomic section below).

\subsection{Taxonomy of New Mitrolithus Species}

The genus Mitrolithus is a typical Lower Jurassic taxon, currently represented by three species, namely M. elegans (the type species), M. jansae and M. lenticularis. The morphological characters of the three Mitrolithus species are illustrated in Figure 3. The common and morphologically diverse assemblage of Mitrolithus observed in the Kermanshah area con- 
tains the three species, as well as previously undescribed types, which are morphologically similar to M. elegans. However, significant differences in the spine and coccolith size and shape justify the introduction of new species.

Deflandre, in Deflandre and Fert [35] (p. 148), established the genus Mitrolithus and described it as "Discolithe en cuvette dont le centre porte une protubérance massive évasée, $\mathrm{d}^{\prime}$ allure fongiforme, donnant à la vue latérale I'aspect d'une mitre" ("A bowl-shaped discolith the central area of which bears a massive flaring mushroom-shaped protuberance, giving the lateral view the appearance of a mitre", after Young et al. [36]). Bown and Young, in Young et al. [36] (p. 129), emended the diagnosis of Mitrolithus as follows: "Coccoliths with an outer rim of thin, broad calcite laths orientated perpendicular to the base and tangential to the ellipse. The central area is filled by a massive boss or spine consisting of several superimposed cycles of radial calcite elements. The spine sits in the coccolith rim on an inner cycle of elements and is attached via a narrow, hollow spine base".

Mitrolithus elegans (Figure 3A) was first described by Deflandre in Deflandre and Fert [35] (p. 148) as: "Cuvette, en vue latérale, un peu évasée, surmontée d'une masse d'abord étroite, puis élargie et arrondie au sommet", which can be translated as "Basket-like discolith slightly tapering in side view, surmounted by a protuberance narrow at its base and flared upwards, ending up with a rounded top". The prominent distal rim cycle is composed of tangential rectangular elements, which are vertically arranged to form a tall, basket-like structure. The proximal rim cycle is composed of prismatic elements infilling the central area around a central hole, which is the base of the hollow spine. The proximal rim cycle elements have distal extensions forming an inner cycle lower than the distal rim cycle, thus having a canine-teeth shape in side view against the inner surface of the distal rim cycle. The spine originates from the coccolith base as a narrow tube inside the coccolith basket, and then flares out from the coccolith rim with a diameter larger than that of the coccolith rim. Its upper surface is domed. The spine is thus lenticular in cross-section, circular in plan-view, and composed of flat, superimposed wedge-shaped elements. Such elements have a plate c-axis, tangential to the longitudinal axis of the spine. Detached spines occur very often, and have been described as Alvearium dorsetense [34].

The second species of Mitrolithus recorded in the Kermanshah area is M. jansae (Figure 3B). The earliest paper to describe this species was Prins [37], who used the name Mitrolithus irregularis. This name was invalid because Prins presented a very clear drawing (Figure 3(B5)), but the species was not formally described with a designated holotype. Later, Wiegand [38] (p. 1152) described this species as Calcivascularis jansae, having the characteristics of the genus, namely: "A basket shaped nannolith filled with a core consisting of many radially arranged elements". Eventually, Young et al. [36] suggested that the specific name jansae should stand as the first valid description of the coccolith, but that the genus Calcivascularis is redundant, because $M$. elegans and $M$. jansae appear to be very closely related, and the genus Calcivascularis is otherwise monospecific. Bown and Young in Young et al. [36] (pp. 130-131) thus recombined Calcivascularis jansae into Mitrolithus jansae, having exactly the same characteristics of the genus Mitrolithus. The rim of M. jansae, composed of rectangular elongated elements, has a narrow truncated-cone shape, slightly elliptical in cross-section. The spine (or core in the original diagnosis) is lodged within the rim, and is constructed of several superimposed cycles, each composed of radial elements. The overall structure of the coccolith is very bulky and the spine/core is mostly enclosed by the coccolith rim. A high degree of rim height variability has been observed [39] (plate 1, figure 27). The coccolith is often observed in side view and more rarely in proximal/distal view. In such specimens, the radial elements of the spine are visible. In very overgrown specimens, the rectangular laths of the distal shield can be enlarged and form a rosette-like structure surrounding the core in proximal view. Such poorly preserved specimens have been considered Rucinolithus sp. by Casellato and Erba [39] (plate 2, figures 16 and 17).

The third species of Mitrolithus recorded in the Kermanshah area is M. lenticularis (Figure 3C). Bown [8] (p. 28) introduced the species, Mitrolithus lenticularis, which possesses "... a spine which completely fills the central area and has a domed upper surface which 
coincides with the rim top; the spine is irregularly structured and oval in plan-view." Mitrolithus lenticularis is distinguished from M. elegans by its smaller size, lower distal shield rim, and a domed spine never higher than the distal shield. The spine is therefore included within the coccolith rim and detached spines are not observed. Overall, $M$. lenticularis has a rugby-ball shape and can be often observed tilted, rather than in side or proximal/distal view.

Bown [8] relates that a number of specimens from Timor (Indonesia) resembling $M$. elegans displayed a noticeable "elevation of the spine due to an increased number of superimposed rings of equal diameter forming a broad, parallel-sided column before terminating in the domed top" (plate 3, figures 14 and 15). Similar specimens occur abundantly in the Kermanshah area, in the uppermost Sinemurian or lowermost Pliensbachian, of both the Kani Sad and Sad sections. Such specimens, along with some other peculiar coccoliths, are herein described as three new Mitrolithus species.

\section{Mitrolithus montgolfieri sp. nov. Mattioli in Abdi et al.}

Figure 4, micrographs A (1-4), text-figure A (5)

Diagnosis. A species of Mitrolithus with a relatively small basket-like rim and a large boss/spine resting on the distal side of the rim. The spine possesses a very typical hot-airballoon shape, made of radially arranged elements forming a globular, hollow space in its center.

Description. A coccolith with a protolith rim structure quite similar to that of M. elegans, but slightly narrower and smaller (see holotype dimensions below). The central area is reduced and surmounted by a bulbous spine resting on the rim. The basket-like rim is small relative to the spine. The latter typically presents an empty globular cavity in its center.

Dimensions of the holotype. Coccolith rim length: $5.4 \mu \mathrm{m}$; coccolith rim height: $2.8 \mu \mathrm{m}$; coccolith rim plus spine height: $6.2 \mu \mathrm{m}$.

Differentiation. Mitrolithus montgolfieri sp. nov. differs from M. elegans because of the smaller dimensions of the basket-like rim and, mainly, for the very peculiar structure of the spine. It differs from $M$. jansae because of the reduced height of the rim and from $M$. lenticularis because of the narrower basket-like rim and the bulbous spine flaring from it.

Derivation of name. From the Montgolfier brothers, inventors of the hot-air balloon, referring to the spine shape.

Holotype. Figure 4(A1), sample J.0-28. Repository: Collections de Géologie de Lyon, FSL N 769033.

Type level. Uppermost Sinemurian, sample J.0-28, J.0 informal lithological member.

Type locality. Iran, Sad section $\left(34^{\circ} 19^{\prime} 1.1^{\prime \prime} \mathrm{N}\right.$ and $\left.47^{\circ} 02^{\prime} 03.8^{\prime \prime} \mathrm{E}\right)$.

Occurrence. Type material, uppermost Sinemurian.

\section{Mitrolithus pseudonannoconus sp. nov. Mattioli in Abdi et al.}

\section{Figure 4, micrographs B(1-5), text-figures B(6)}

Diagnosis. A species of Mitrolithus with a very low rim and a prominent, flaring spine, made of radial elements, longitudinally crossed by a well-distinguished canal.

Description. Mitrolithus pseudonannoconus sp. nov. possesses a basket-like rim, very reduced in size, closely placed against the prominent spine. The rim can sometimes be extremely low, and poorly visible at the base of the spine (Figure 4(B1-5)). The spine possesses a structure flaring distally and is flat at its top. The radial calcite elements forming the spine delineate an axial canal, which is easily visible using an optical microscope. Isolated spines do occur, which can be misleading as they closely resemble the morphology of a Nannoconus with an intermediate-sized axial canal. 
Differentiation. Mitrolithus pseudonannoconus sp. nov. is a very distinctive form of Mitrolithus, which differs from all other species because of the very reduced dimensions (height) of the basket-like rim and the peculiar structure of the spine, which is multi-layered and with a trapezoidal shape in side view.

Remarks. There is a morphological transition from specimens with a reduced basketlike rim, until this is extremely reduced and sometimes lacking. Those specimens look very similar to a Nannoconus with an intermediate-sized axial canal.

Derivation of name. From the greek word $\psi \varepsilon v \delta \bar{\eta} \varsigma$ (pseudes) meaning false, and Nannoconus, the Cretaceous nannoliths.

Dimensions of the holotype. Coccolith rim length: $2.9 \mu \mathrm{m}$; coccolith rim height: $1.1 \mu \mathrm{m}$; coccolith rim plus spine height: $5 \mu \mathrm{m}$.

Holotype. Figure 4(B1), sample J.0-26. Repository: Collections de Géologie de Lyon, FSL N $\mathrm{N}^{\circ} 769031$.

Type level. Uppermost Sinemurian, sample J.0-26, J.0 informal lithological member.

Type locality. Iran, Sad section $\left(34^{\circ} 19^{\prime} 11.1^{\prime \prime} \mathrm{N}\right.$ and $\left.47^{\circ} 02^{\prime} 03.8^{\prime \prime} \mathrm{E}\right)$.

Occurrence. Type material, uppermost Sinemurian.

\section{Mitrolithus tethysiensis sp. nov. Mattioli and Bown in Abdi et al.}

Figure 4, micrographs $\mathrm{C}(1-6,8)$, text-figure $\mathrm{C}(7)$

1987 Mitrolithus elegans Bown [8], pl. 3, figures 14 and 15

Diagnosis. A Mitrolithus species with a very prominent spine due to an increased number of superimposed cycles of elements forming a broad, parallel-sided column before terminating in a domed top.

Description. A large coccolith, with a typical Mitrolithus basket-like rim, surmounted by a very large boss/spine mostly resting on the inner rim cycle. The spine is raised above the rim, because (as for M. elegans) the spine base is narrow before flaring out distally. The spine is very thick in side view, with a superimposed series of radial elements surrounding a narrow axial canal.

Differentiation. This is a very distinctive Mitrolithus species, very different from the other Mitrolithus species because of the peculiar shape of its spine.

Remarks. Bown [8] reported similar specimens from a Timor sample (J237), and interpreted them as $M$. elegans, because of the quite similar coccolith architecture. However, he noticed the very peculiar, multi-layered spine, which justifies the introduction of a new species.

Derivation of name. From Tethys Ocean, because the two localities where this new species has been recorded (Timor and Iran) are located in the eastern Tethys.

Dimensions of the holotype. Coccolith rim length: $4.1 \mu \mathrm{m}$; coccolith rim height: $2.1 \mu \mathrm{m}$; coccolith rim plus spine height: $6.95 \mu \mathrm{m}$.

Holotype. Figure 4(C1), sample J.0-28. Repository: Collections de Géologie de Lyon, FSL N $\mathrm{N}^{\circ} 769033$.

Type level. Uppermost Sinemurian, sample J.0-28, J.0 informal lithological member. Type locality. Iran, Sad section $\left(34^{\circ} 19^{\prime} 11.1^{\prime \prime} \mathrm{N}\right.$ and $\left.47^{\circ} 02^{\prime} 03.8^{\prime \prime} \mathrm{E}\right)$.

Occurrence. Type material, uppermost Sinemurian. 

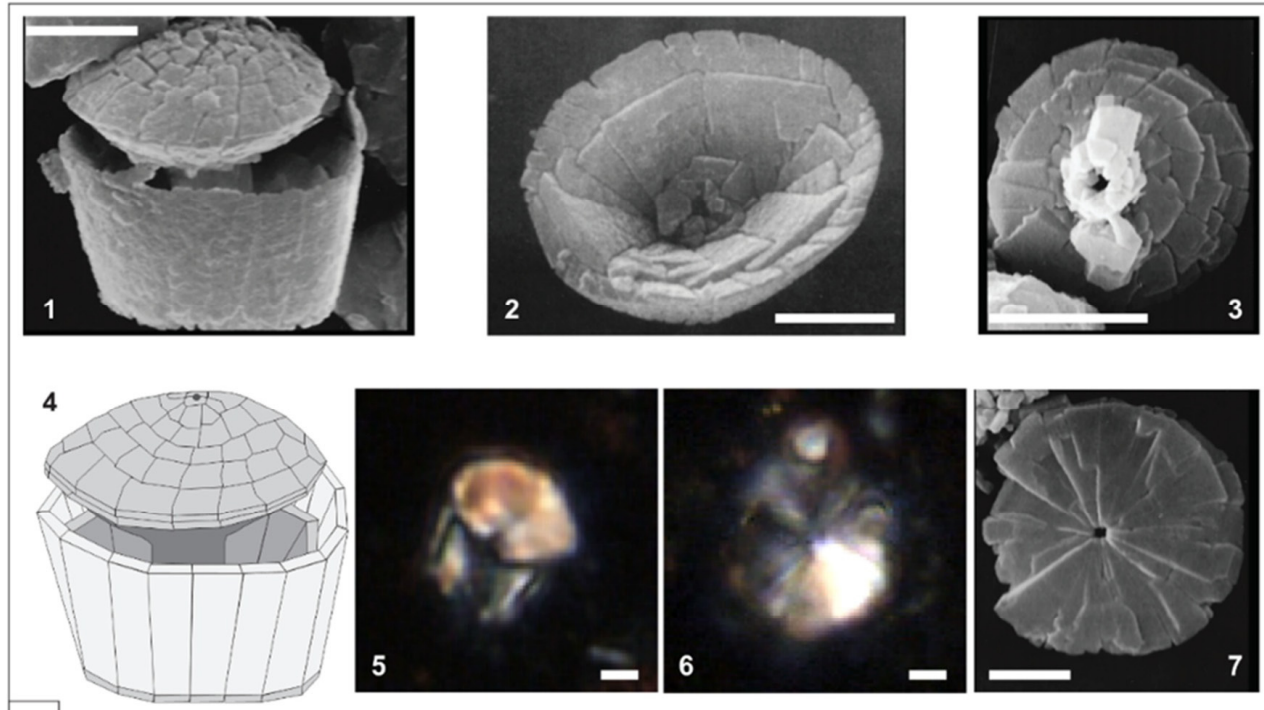

A

Mitrolithus elegans

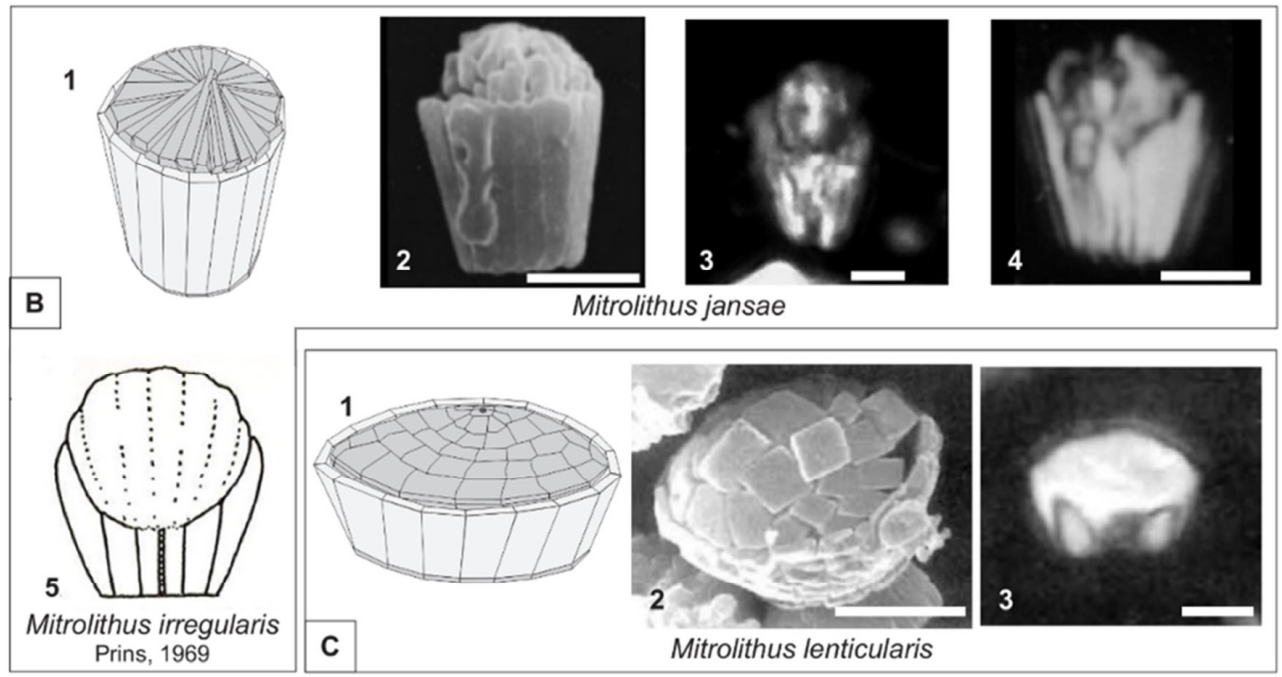

Figure 3. The three species of Mitrolithus known nowadays, as represented in the literature, with schematic drawings illustrating their main morphological features. The white scale bar is $2 \mu \mathrm{m}$. (A) Mitrolithus elegans: 1. SEM image of a side-view coccolith, modified after Bown [8] (plate 3 figure 7); 2. SEM image of a distal-view coccolith without the spine (modified after Bown [40], plate 3 figure 1); 3. SEM image of an isolated spine, proximal view (the broken spine is still visible), modified after Bown [8] (plate 3 figure 10); 4. Sketch redrawn from the SEM image in 1. 5. A side-view specimen recorded in the Kermanshah area (sample J.0-28) under optical microscope, crossed polars. 6. An isolated spine in distal view recorded in the Kermanshah area (sample J.0-28) under optical microscope, crossed polars. 7. SEM image of an isolated spine, distal view, after Bown [8] (plate 3 figure 12). (B) Mitrolithus jansae: 1. Sketch redrawn from SEM images; 2. SEM image of a side-view coccolith, modified after Bown and Cooper [41] (plate 1 figure 11); 3. A side-view specimen under optical microscope, crossed polars modified after Menini et al. [42] (plate 1 figure 14). The calcite laths forming the distal shield appear light grey, while the highly birefringent elements inside these laths, as high as two-thirds of the rim, likely correspond to the proximal shield elements, which are rarely visible due to the bulky structure of the coccolith; 4 . A side-view specimen under optical microscope, crossed polars, modified after Bown and Cooper [33] (plate 1 figure 16); 5. The sketch of M. irregularis figured as nomen nudum by Prins [37] and interpreted as it was derived from M. elegans. (C) Mitrolithus lenticularis: 1. Sketch redrawn from SEM images; 2. SEM image of a side/distal-view coccolith (holotype), modified after Bown [8] (plate 4 figure 7); 3. A side-view specimen under optical microscope, crossed polars modified after Bown [8] (plate 12 figure 29). 

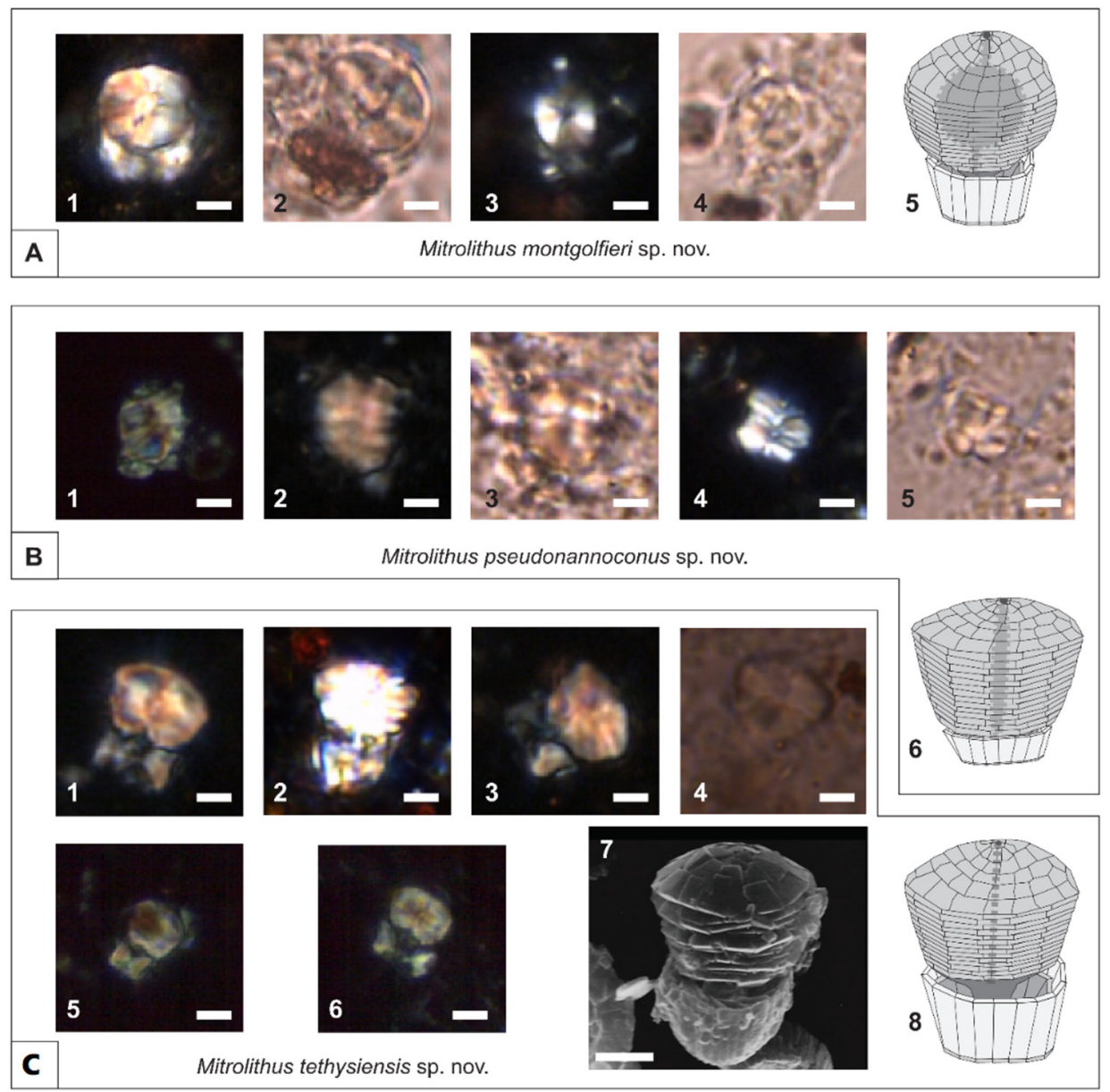

Figure 4. Micrographs showing the new species of Mitrolithus introduced in this work, as well as schematic drawings illustrating their main morphological features. The white scale bar is $2 \mu \mathrm{m}$. (A) M. montgolfieri: 1. Holotype in side view with a small-sized basket-like rim, under optical microscope, crossed polars (sample J.0-26); 2. Specimen in side view, with a small basket-like rim, under optical microscope, crossed polars (sample J.0-28); 3. Same specimen as 2 in parallel polars; 4. Specimen in side view, with a small basket-like rim, under optical microscope, crossed polars (sample J.0-28); 5. Same specimen as 4 in parallel polars. (B) M. pseudonannoconus: 1 . holotype, specimen in side-view, with a small-sized basket like rim, under optical microscope, crossed polars (sample J.0-26); 2. specimen in side-view, with a small-sized basket like rim, under optical microscope, crossed polars (sample J.0-28); 3. same specimen as 2 in parallel polars; 4 . specimen in side-view, with a small-sized basket like rim, under optical microscope, crossed polars (sample J.0-28); 5. same specimen as 9 in parallel polars. 6. schematic drawing side-view for specimens displaying an extremely reduced rim. (C) M. tethysiensis; 1 . Holotype, side-view specimen under optical microscope, crossed polars (sample J.0-28); 2. Side-view specimen under optical microscope, crossed polars (sample J.0-28); 3. Side-view specimen under optical microscope, crossed polars (sample J.0-28); 4. Same specimen as 3 in parallel polars; 5 . Specimen in side view, with a smaller basket-like rim, under optical microscope, crossed polars (sample J.0-28); 6. Specimen in side view, with a smaller basket-like rim, under optical microscope, crossed polars (sample J.0-28); 7. Schematic drawing side view; 8. Side view in SEM of the specimen figured by Bown [8] from Timor (sample J237, micrograph UCL-2072-23).

\section{Discussion}

\subsection{Calcareous Nannofossil Biostratigraphy}

The calcareous nannofossil assemblage composition of the Kermanshah area clearly presented a south Tethyan affinity, given the richness in Mitrolithus species and the presence of Mazaganella pulla in the assemblage $[8,43]$. The presence within the base of the J.1 
member in the Kani Sad section of M. lenticularis allows for dating of the section to the NJT 3b nannofossil subzone of Mattioli and Erba [10] and Ferreira et al. [11] (Figure 2; Table S1). This interval indicates a late Sinemurian age for the J.1 member. A Sinemurian age was further supported by the sporadic presence of P. marthae in the J.1 member of Kani Sad section. This species is reported to disappear in the lower Sinemurian by Bown [8] and in the uppermost Sinemurian by Ferreira et al. [11]. Parhabdolithus marthae is therefore restricted to the Sinemurian. Mazaganella (M. pulla or M. protensa) has been sporadically recorded in the J.0 member of both Kani Sad and Sad sections; the NJT 3c subzone of Ferreira et al. [11] cannot be therefore identified. This subzone was thus merged into the NJT 3b-c (Figure 2 and Table S1).

The FO of the Similiscutum group was recorded in both sections in the shaly part of the J.0 member (Figure 2 and Table S1). This peculiar event is consistently used by various authors to designate the NJT 4 zone (NJT 4a subzone), both in northwest and southwest Tethys regions $[10,11,33]$. The occurrence of Similiscutum is very relevant because the NJT 4a subzone can be used to detect the base of the Pliensbachian when other diagnostic fossils (e.g., ammonites) are lacking.

The new calcareous nannofossil biostratigraphy established here is partly in contrast with previous Pliensbachian to early Toarcian age assignments of the successions by means of radiolarians $[1,23,24]$, and also encourages reconsideration of the correct stratigraphic position of the lithological successions. In particular, based on calcareous nannofossil data, the J.1 and J.2 members of Abdi et al. $[1,23,24]$ are in fact in an inverted position (Table 1). The new J.1 member used here (pelagic limestones and marls of the previous J.2 member of Abdi et al. $[1,23,24])$ belongs to the upper Sinemurian NJT 3b subzone, whereas the new J.0 member made of cherts and shales (part of the previous J.1 member of Abdi et al. $[1,23,24]$ ) encompasses the uppermost Sinemurian NJT 3b-c subzone and the lowermost Pliensbachian NJT 4a subzone. The area is tectonically affected and the J.1 member is thrusted over the J.0 member. In the lowermost part of the J.1 member (J.2 in Abdi et al. $[1,23,24])$ of the Kani Sad section, the occurrence of the radiolarians Praeconocaryomma bajaensis and Bagotum modestum (which were used to interpret a Pliensbachian p.p. or early Toarcian age for this member) is compatible with an end-Sinemurian to earliest Pliensbachian age. In fact, Bagotum modestum first occurs in the UA 2 zone of Carter et al. [2], which spans the Sinemurian-Pliensbachian boundary. Praeconocaryomma bajaensis is also recorded from the lowermost Pliensbachian [2].

\subsection{Evolutionary and Paleogeographic Implications of the New Mitrolithus Species}

One of the most prominent features of the calcareous nannofossil assemblages of the Kermanshah area is the finding of a very common and diverse assemblage of Mitrolithus species (including three new ones) in the uppermost Sinemurian and lowermost Pliensbachian. In particular, two of the three newly described species have never been documented elsewhere, although observed offshore Australia (Richard Howe, personal communication, 2019). Conversely, M. tethysiensis was previously reported by Bown [8] from a single Timor Island sample (J237), dated to the mid-Pliensbachian, but without any precise information regarding the age determination of the studied material. The absence of such species in classical and thoroughly studied localities of comparable age in the western Tethys is intriguing. On the basis of the presence of endemic species, Bown [8] inferred a separate Pacific-Tethys Realm, including the south-eastern margin of Tethys to which the Kermanshah area belongs. However, no physical barrier is known between the eastern and the western Tethys (Figure 1A,B), and most of the Lower Jurassic nannofossil species are known to be cosmopolitan and successful throughout the marine environment [8]. Thus, at this stage it is difficult to explain such a limited distribution of the new Mitrolithus species. However, M. jansae, which is typically recorded at low-latitude Tethys sites [8], is considered to have behaved as a deep-dweller [44-46], thriving in the deep photic zone in a manner similar to the living species Florisphaera profunda [47]. If so, the intensity of sunlight irradiance was likely not sufficient at higher latitudes to support the development 
of M. jansae [43]. Additionally, F. profunda abundance sharply decreases between $30^{\circ}$ and $40^{\circ} \mathrm{N}$ in the Pacific [48]. In this view, it is likely that the ecological requirements (in terms of light, nutrients, or other) of M. montgolfieri, M. pseudonannoconus and M. tethysiensis were only compatible with the low-latitude southeast margin of the Tethys. Alternatively, these species were likely not competitive enough with respect to other, well-established western Tethys species thriving in the deep photic zone environment, such as Crepidolithus crassus [43,48-53].

The spine morphologies of the newly described species are also very intriguing, in that they closely resemble the Nannoconus shape. M. pseudonannoconus sp. nov. has a reduced coccolith rim, with the spine dominating the coccolith (Figure 4B), and isolated spines being commonly recorded. From a crystallographic point of view, the spines are made of calcite crystals with a plate c-axis, and a tangential to longitudinal axis of the spine. These crystals appear low birefringent when the spine is seen in distal view (Figure 3(A6)), while in side view the spine may present second-order orange colors (Figure 4(A1,B2,C1-3)). This optical behavior is very similar to Nannoconus nannoliths, where the plate c-axes are arranged tangentially to the longitudinal axis. These morphological and crystallographic similarities between the spines of Lower Jurassic Mitrolithus species and Cretaceous incertae sedis, if not fortuitous, are very difficult to explain. However, both Mitrolithus and Nannoconus are well known as having been typical components of Tethys nannoplankton assemblages. As for some Mitrolithus species (e.g., M. jansae), a deep-dweller habitat has been inferred for nannoconids [54]. Thus, they might both represent organisms that independently adopted similar shapes in a process of morphological convergence. Interestingly, Mitrolithus (especially $M$. jansae) possesses a cone-like morphology strikingly similar to the Triassic genus Eoconusphaera and the Upper Jurassic/Lower Cretaceous genus Conusphaera, all being typically and abundantly recorded at low latitudes in the Tethyan domain. Such homeomorphy is puzzling because these taxa are recorded at present with mutually exclusive stratigraphic distributions [33]. The results of this paper showing homeomorphy for the inner core structures (i.e., the Mitrolithus spine) and the Cretaceous Nannoconus should enable a better overview of the evolution of conical calcareous nannofossils in the Mesozoic.

\section{Conclusions}

A common and diverse calcareous nannofossil assemblage is documented for the first time in this account from the Lower Jurassic shale, chert and pelagic limestone succession of the Kermanshah Basin (Kani Sad and Sad sections, western Iran, West Zagros). The new nannofossil record shown in this account and the re-examination of the range of radiolarian species challenge the former Pliensbachian to early Toarcian age assignment of the studied successions. In fact, the recorded radiolarian species proved to be long-ranging taxa, the earliest occurrence of which is consistent with the late Sinemurian-early Pliensbachian age provided by calcareous nannofossil assemblages and events. In particular, the last occurrence of Parhabdolithus marthae (a typical Sinemurian taxon) and the first occurrence of the Similiscutum group (lower Pliensbachian) allow for the recognition in the two sections of the nannofossil subzones NJT 3b-c and NJT 4a. These results also allow for a better understanding of the stratigraphic position of the sedimentary units. In fact, the two studied sections represent the $\mathrm{N}$ and $\mathrm{S}$ limbs of a syncline over-thrusted by the radiolarite units.

Besides these stratigraphic and structural implications, the analysis of nannofossil assemblages of the Kermanshah area revealed the presence of specimens of the genus Mitrolithus never before described, allowing for the formal definition of three new species: M. montgolfieri, M. pseudonannoconus, and M. tethysiensis. The two former species present a very peculiar morphology of the spine structure infilling the central area of the coccolith, and isolated spines resemble the morphology of Cretaceous nannoconids. Such records address the question of morphological convergence or homeomorphy for two nannofossil taxa (Mitrolithus and Nannoconus), which have a mutually exclusive stratigraphic distribution (Lower Jurassic and Cretaceous, respectively), but are both typical of low-latitude, warm-water Tethyan settings. Mitrolithus tethysiensis was previously described from a 
single sample from Timor (Indonesia) and considered a modified specimen of M. elegans. The abundant record of $M$. elegans, along with the three newly described species in the Kermanshah area, and the fact that the new species have never before been recorded in the well-studied western Tethys setting, support a strong endemism of calcareous nannofossil assemblages in the Jurassic.

Supplementary Materials: The following supporting information can be downloaded at: https:// www.mdpi.com/article/10.3390/geosciences12020059/s1, Table S1: Distribution chart of calcareous nannofosil taxa recognized in Kani Sad and Sad sections, within the members J.0 and J.1 as redefined in the present work.

Author Contributions: Conceptualization, A.A. and E.M.; methodology, E.M.; validation, A.A., E.M. and B.B.; formal analysis, E.M.; investigation, A.A., E.M. and B.B.; data curation, E.M.; writingoriginal draft preparation, A.A. and E.M.; writing-review and editing, A.A., E.M. and B.B.; visualization, A.A. and E.M.; supervision, A.A.; project administration, A.A.; funding acquisition, E.M. All authors have read and agreed to the published version of the manuscript.

Funding: IUF 2017 to E.M. NOR: MENS1700286A.

Institutional Review Board Statement: Not applicable.

Informed Consent Statement: Not applicable.

Data Availability Statement: Slides and data are curated at the Collections de Géologie de Lyon (http:/ / lgltpe.ens-lyon.fr/ressources / collections-1 accessed on 18 December 2021) with the FSL $\mathrm{N}^{\circ}$ from 769015 to 769091 .

Acknowledgments: A preliminary version of this paper benefitted from insightful review and inspiring comments by Paul R. Bown. We wish to warmly thank Ghislaine Broillet for the preparation of smear slides for calcareous nannofossil analysis and Zaminrizkavan Co., Ltd. for assistance during fieldwork and petrographic studies. This work is a contribution to the IGCP-655 project (UNESCOIUGS). The research of B. Bádenas is supported by Group E18: Aragosaurus: Recursos Geológicos y Paleoambientales.

Conflicts of Interest: The authors declare no conflict of interest.

\section{Appendix A}

List of the species recorded or cited in this paper.

Alvearium dorsetense Black, 1965

Crepidolithus crassus (Deflandre in Deflandre and Fert, 1954) Noël, 1965

Small-sized Crepidolithus crassus described in Suchéras-Marx et al. (2010)

Crepidolithus cavus Prins, 1969

Crepidolithus crucifer Rood et al. 1973

Crepidolithus granulatus Bown, 1987a

Crepidolithus impontus Grün et al., 1974

Crepidolithus timorensis Kristan-Tollmann, 1988

Crucirhabdus aff. C. minutus Jafar, 1983

Crucirhabdus primulus Prins 1969 ex Rood et al., 1973, emended Bown, 1987a

Mazaganella protensa Bown, 1987a

Mazaganella pulla Bown, 1987a

Mitrolithus elegans Deflandre in Deflandre and Fert, 1954

Mitrolithus jansae (Wiegand, 1984) Bown in Young et al., 1986

Mitrolithus lenticularis Bown, 1987a

Mitrolithus montgolfieri sp. nov.

Mitrolithus pseudonannoconus sp. nov.

Mitrolithus tethysiensis sp. nov.

Parhabdolithus liasicus subsp. distinctus Bown, 1987a

Parhabdolithus liasicus subsp. liasicus Bown, 1987a

Parhabdolithus marthae Deflandre in Deflandre and Fert, 1954

Parhabdolithus robustus Noël, 1965 


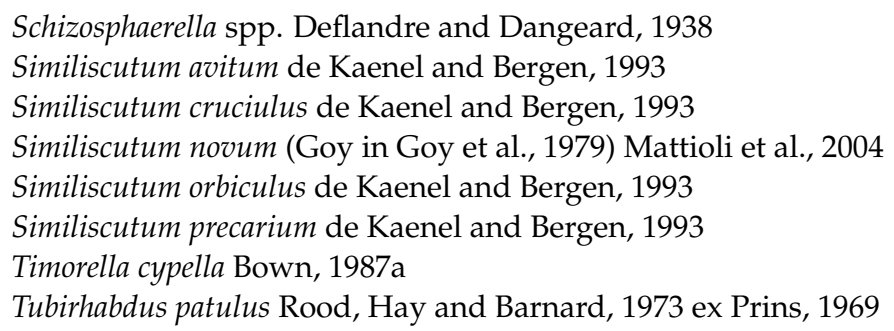

\section{References}

1. Abdi, A.; Gharaie, M.H.M.; Bádenas, B. Internal wave deposits in Jurassic Kermanshah pelagic carbonates and radiolarites (Kermanshah area, West Iran). Sediment. Geol. 2014, 314, 47-59. [CrossRef]

2. Carter, E.S.; Goričan, Š.; Guex, J.; O’Dogherty, L.; De Wever, P.; Dumitrica, P.; Hori, R.S.; Matsuoka, A.; Whalen, P.A. Global radiolarian zonation for the Pliensbachian, Toarcian and Aalenian. Palaeogeogr. Palaeoclim. Palaeoecol. 2010, 297, 401-419. [CrossRef]

3. O'Dogherty, L.; Carter, E.S.; Dumitrica, P.; Goriččan, Š.; Wever, P.D.; Bandini, A.N.; Baumgartner, P.O.; Matsuoka, A. Catalogue of Mesozoic Radiolarian Genera. Part 2: Jurassic-Cretaceous. Geodiversitas 2009, 31, 271-356. [CrossRef]

4. Barnard, T.; Hay, W.W. On Jurassic coccoliths: A tentative zonation of the Jurassic of Southern England and North France. Eclogae Geol. Helv. 1974, 67, 563-585.

5. Hamilton, G. Lower and Middle Jurassic calcareous nannofossils from Portugal. Eclogae Geol. Helv. 1979, 72, 1-17.

6. Hamilton, G.B. Triassic and Jurassic Calcareous Nannofossils. In A Stratigraphical Index of Calcareous Nannofossils; Ellis Horwood: Chichester, UK, 1982; pp. 17-39.

7. Medd, A.W.; Medd, A.W. Nannofossil Zonation of the English Middle and Upper Jurassic Jurassic. Mar. Micropaleontol. 1982, 7, 73-95. [CrossRef]

8. Bown, P.R. Taxonomy, evolution and biostratigraphy of Late Triassic-Early Jurassic calcareous nannofossils. Spec. Pap. Palaeontol. 1987, 38, 118

9. Bown, P.; Cooper, M.K.E.; Lord, A.R. A Calcareous Nannofossil Biozonation Scheme for the early to mid Mesozoic. Newsl. Strat. 1988, 20, 91-114. [CrossRef]

10. Mattioli, E.; Erba, E. Biostratigraphic Synthesis of Calcareous Nannofossil Events in Tethyan Jurassic. Riv. Ital. Paléontol. Strat. 1999, 105, 343-376. [CrossRef]

11. Ferreira, J.; Mattioli, E.; Suchéras-Marx, B.; Giraud, F.; Duarte, L.; Pittet, B.; Suan, G.; Hassler, A.; Spangenberg, J.E. Western Tethys Early and Middle Jurassic calcareous nannofossil biostratigraphy. Earth-Sci. Rev. 2019, 197, 102908. [CrossRef]

12. Cornée, J.-J.; Martini, R.; Villeneuve, R.; Zaninetti, L.; Mattioli, E.; Rettori, R.; Atrops, F.; Gunawan, W. Jurassic Pelagic Deposits of East Sulawesi (Kolonodale Area, Indonesia): New Biostratigraphic Data Based on Calcareous Nannofossils. Geoitalia 1999, 32, 385-394.

13. Shafik, S.; Organisation, A.G.S. Significance of Calcareous Nannofossil-Bearing Jurassic and Cretaceous Sediments on the Rowley Terrace, Offshore Northwest Australia. Available online: https://researchdata.edu.au/significance-calcareous-nannofossilnorthwest-australia/ 688200 (accessed on 9 December 2021).

14. Kazmin, V.; Ricou, L.-E.; Sbortshikov, I.M. Structure and Evolution of the Passive Margin of the Eastern Tethys. Tectonophysics 1986, 123, 153-179. [CrossRef]

15. Bassoulet, J.P.; Elmi, S.; Poisson, A.; Cecca, F.; Bellion, Y.; Guiraud, R.; Baudin, F. Mid Toarcian. In Atlas Tethys Palaeoenvironmental Maps; Dercourt, J., Ricou, L.E., Vrielynck, B., Eds.; BEICIP-FRANLAB: Rueil-Malmaison, France, 1993; pp. 63-84.

16. Robertson, A.H.F. Overview of tectonic settings related to the rifting and opening of Mesozoic ocean basins in the Eastern Tethys: Oman, Himalayas and Eastern Mediterranean regions. In Imaging, Mapping and Modelling Continental Lithosphere Extension and Breakup; Karner, G., Manatschal, G., Pinheiro, L.M., Eds.; Geological Society London Special Publications: Bath, UK, 2007; Volume 282, pp. 325-388. [CrossRef]

17. Gharib, F.; De Wever, P. Radiolaires mésozoïques de la formation de Kermanshah (Iran). C. R. Palevol. 2010, 9, 209-219. [CrossRef]

18. Navabpour, P.; Angelier, J.; Barrier, E. Brittle tectonic reconstruction of palaeo-extension inherited from Mesozoic rifting in West Zagros (Kermanshah, Iran). J. Geol. Soc. 2011, 168, 979-994. [CrossRef]

19. Berra, F.; Angiolini, L.; Muttoni, G. The Evolution of the Tethys Region throughout the Phanerozoic: A Brief Tectonic Reconstruction. In Memoir 106: Petroleum Systems of the Tethyan Region; Marlow, L., Kendall, C.C.G., Rose, L.A., Eds.; AAPG: Tulsa, OK, USA, 2014; pp. 1-27.

20. Mohajjel, M.; Fergusson, C.L.; Sahandi, M.R. Cretaceous-Tertiary Convergence and Continental Collision, Sanandaj-Sirjan Zone, Western Iran. J. Asian Earth Sci. 2003, 21, 397-412. [CrossRef]

21. Abdi, A.; Bádenas, B.; Gharaie, M.H.M.; Gorican, S.; Toodekesht, S.; Mattioli, E. The Story of Kermanshah Radiolarite Basin from Early Jurassic to Late Cretaceous. In Proceedings of the 3rd Trigger International Conference, Zanjan, Iran, 5-6 October 2019; Institute for Advanced Studies in Basic Sciences: Zanjan, Iran, 2019.

22. Wrobel-Daveau, J.-C.; Ringenbach, J.-C.; Tavakoli, S.; Ruiz, G.M.H.; Masse, P.; Frizon de Lamotte, D. Evidence for Mantle Exhumation along the Arabian Margin in the Zagros (Kermanshah Area, Iran). Arab. J. Geosci. 2010, 3, 499-513. [CrossRef] 
23. Abdi, A. Sedimentology and Geochemistry of Kermanshah Radiolarite Complex with Special Reference to Depositional Environment; Doctoral-Ferdowsi University of Mashhad: Mashhad, Iran, 2016.

24. Abdi, A.; Gharaie, M.H.M.; Bádenas, B. Radiolarian productivity linked to climate conditions during the Pliensbachian-Aalenian in the Kermanshah Basin (West Iran). Facies 2016, 62, 30. [CrossRef]

25. Alavi, M.; Mahdavi, M.A. Stratigraphy and structures of the Nahavand region in western Iran, and their implications for the Zagros tectonics. Geol. Mag. 1994, 131, 43-47. [CrossRef]

26. Agard, P.; Omrani, J.; Jolivet, L.; Mouthereau, F. Convergence history across Zagros (Iran): Constraints from collisional and earlier deformation. Geol. Rundsch. 2005, 94, 401-419. [CrossRef]

27. Braud, J. La Suture du Zagros au Niveau de Kermanshah (Kurdistan Iranien): Reconstitution Paléogéographique: Évolution Géodynamique, Magmatique et Structurale; Université de Paris-Sud: Paris, France, 1987; p. 11.

28. Blakey, R.C. Gondwana Paleogeography from Assembly to Breakup-A 500 m.y. Odyssey. In Special Paper 441: Resolving the Late Paleozoic Ice Age in Time and Space; Geological Society of America: Boulder, CO, USA, 2008; Volume 441, pp. 1-28.

29. Mattioli, E.; Pittet, B.; Young, J.R.; Bown, P.R. Biometric Analysis of Pliensbachian-Toarcian (Lower Jurassic) Coccoliths of the Family Biscutaceae: Intra- and Interspecific Variability versus Palaeoenvironmental Influence. Mar. Micropaleontol. 2004, 52, 5-27. [CrossRef]

30. Bown, P.R.; Young, J.R. Techniques. In Calcareous Nannofossil Biostratigraphy; British Micropalaeontological Society Publications Series; Bown, P.R., Ed.; Chapman and Kluwer Academic: London, UK, 1998; pp. 16-28.

31. Roth, P.H. Preservation of Calcareous Nannofossils and Fine-Grained Carbonate Particles in Mid-Cretaceous Sediments from the Southern Angola Basin. In Initial Reports of Deep Sea Drilling Project 75; Hay, W.W., Ed.; U.S. Government Printing Office: Washington, DC, USA, 1984; pp. 651-655.

32. De Kaenel, E.; Bergen, J.A. New Early and Middle Jurassic Coccolith Taxa and Biostratigraphy from the Eastern Proto-Atlantic (Morocco, Portugal and DSDP Site 547 B). Eclogae Geol. Helv. 1993, 86, 861-907.

33. Bown, P.R.; Cooper, M.K.E. Jurassic. In Calcareous Nannofossil Biostratigraphy; Bown, P.R., Ed.; British Micropalaeontological Society Publications Series: London, UK, 1998; pp. 34-85.

34. Black, M. Coccoliths. Endeavour 1965, 24, 131-137.

35. Deflandre, G.; Fert, C. Observations sur les Coccolithophoridés Actuels et Fossiles en Microscopie Ordinaire et Électronique. Ann. Paléontologie 1954, 40, 115-176.

36. Young, J.R.; Teale, C.T.; Bown, P.R. Revision of the Stratigraphy of the Longobucco Group (Liassic, Southern Italy); Based on the New Data on Nannofossils and Ammonite. Eclogae Geol. Helv. 1986, 79, 117-135.

37. Prins, B. Evolution and Stratigraphy of Coccolithinids from the Lower and Middle Lias. In Proceedings of the First International Conference on Planktonic Microfossils, Genève, Switzerland, 27 September-3 October 1969; pp. 547-558.

38. Wiegand, G. Two Genera of Calcareous Nannofossils from the Lower Jurassic. J. Palaeontol. 1954, 58, $1151-1155$.

39. Casellato, C.E.; Erba, E. Calcareous Nannofossil Biostratigraphy and Paleoceanography of the Toarcian Oceanic Anoxic Event at Colle di Sogno Section (Southern Alps, Italy). Riv. Ital. Paleontol. E Stratigr. 2015, 121, 297-327. [CrossRef]

40. Bown, P.R. The Structural Development of Early Mesozoic Coccoliths and Its Evolutionary and Taxonomic Significance. Abh Geol. Bundesanst. 1987, 39, 33-49.

41. Bown, P.R.; Cooper, M.K.E. Conical Calcareous Nannofossils in the Mesozoic. In Nannofossils and Their Applications; Crux, J.A., van Heck, S.E., Eds.; British Micropalaeontological Society Series; Ellis Horwood Ltd.: Chichester, UK, 1989 ; pp. 98-106.

42. Menini, A.; Mattioli, E.; Spangenberg, J.E.; Pittet, B.; Suan, G. New Calcareous Nannofossil and Carbon Isotope Data for the Pliensbachian/Toarcian Boundary (Early Jurassic) in the Western Tethys and Their Paleoenvironmental Implications. Newsl. Stratigr. 2019, 52, 173-196. [CrossRef]

43. Mattioli, E.; Pittet, B.; Suan, G.; Mailliot, S. Calcareous Nannoplankton Changes across the Early Toarcian Oceanic Anoxic Event in the Western Tethys: Implications for Paleoceanography within the Western Tethys. Paleoceanography 2008, 23, 3208. [CrossRef]

44. Bucefalo Palliani, R.; Mattioli, E. Ecology of dinoflagellate cysts and calcareous nannofossils from bituminous facies of the Early Toarcian, central Italy. In Proceedings of the III EPA Workshop: Black Shales Models, Dotternhausen, Germany, 6-8 July 1995; pp. 60-62.

45. Mattioli, E.; Pittet, B. Spatial and temporal distribution of calcareous nannofossils along a proximal-distal transect in the Lower Jurassic of the Umbria-Marche Basin (central Italy). Palaeogeogr. Palaeoclim. Palaeoecol. 2004, 205, 295-316. [CrossRef]

46. Erba, E. Calcareous nannofossils and Mesozoic oceanic anoxic events. Mar. Micropaleontol. 2004, 52, 85-106. [CrossRef]

47. Okada, H.; Honjo, S. The distribution of oceanic coccolithophorids in the Pacific. Deep Sea Res. Oceanogr. Abstr. 1973, 20, 355-374. [CrossRef]

48. Bour, I.; Mattioli, E.; Pittet, B. Nannofacies analysis as a tool to reconstruct paleoenvironmental changes during the Early Toarcian anoxic event. Palaeogeogr. Palaeoclim. Palaeoecol. 2007, 249, 58-79. [CrossRef]

49. Fraguas, Á.; Erba, E. Biometric analyses as a tool for the differentiation of two coccolith species of the genus Crepidolithus (Pliensbachian, Lower Jurassic) in the Basque-Cantabrian Basin (Northern Spain). Mar. Micropaleontol. 2010, 77, 125-136. [CrossRef]

50. Reggiani, L.; Mattioli, E.; Pittet, B.; Duarte, L.; de Oliveira, L.V.; Comas-Rengifo, M. Pliensbachian (Early Jurassic) calcareous nannofossils from the Peniche section (Lusitanian Basin, Portugal): A clue for palaeoenvironmental reconstructions. Mar. Micropaleontol. 2010, 75, 1-16. [CrossRef] 
51. Suchéras-Marx, B.; Mattioli, E.; Pittet, B.; Escarguel, G.; Suan, G. Astronomically-paced coccolith size variations during the early Pliensbachian (Early Jurassic). Palaeogeogr. Palaeoclim. Palaeoecol. 2010, 295, 281-292. [CrossRef]

52. Clémence, M.-E.; Gardin, S.; Bartolini, A. New insights in the pattern and timing of the Early Jurassic calcareous nannofossil crisis. Palaeogeogr. Palaeoclim. Palaeoecol. 2015, 427, 100-108. [CrossRef]

53. Ferreira, J.; Mattioli, E.; Pittet, B.; Cachão, M.; Spangenberg, J.E. Palaeoecological insights on Toarcian and lower Aalenian calcareous nannofossils from the Lusitanian Basin (Portugal). Palaeogeogr. Palaeoclim. Palaeoecol. 2015, 436, 245-262. [CrossRef]

54. Erba, E. Nannofossils and superplumes: The Early Aptian "nannoconid crisis". Paleoceanography 1994, 9, 483-501. [CrossRef] 